Brit. F. vener. Dis. (1967), 43, 181.

\title{
HAEMAGGLUTINATION TEST UTILIZING PATHOGENIC TREPONEMA PALLIDUM FOR THE SERO-DIAGNOSIS OF SYPHILIS*
}

\author{
BY \\ TARA RATHLEV \\ Treponematoses Department, Statens Seruminstitut, Copenhagen, Denmark
}

Haemagglutination reactions for the diagnosis of syphilis were first reported by Blumenthal (1932) and Bachmann (1932), who used an extract of syphilitic liver as the antigen. However, the test yielded both false positive and false negative reactions, rendering it of no diagnostic value. An agglutination test with suspensions of Reiter treponemes was used for testing cerebrospinal fluid by Roemer and Schlipköter (1953). Lamedica and Robert (1957) tried a haemagglutination procedure to investigate the antibodies produced against the soluble Reiter protein antigen. They showed a fairly good correlation between the values of haemagglutination and complement-fixing tests with the same antigen. D'Alessandro (1958) attempted to sensitize human and sheep erythrocytes with lipopolysaccharide antigen from the Reiter treponemes without success. A haemagglutination test with erythrocytes conjugated with pathogenic treponemal antigen for the diagnosis of syphilis was first reported by Rathlev (1965).

The present study summarizes results obtained from investigations on 300 human sera, including normal, syphilitic, and several non-treponemal or biological false positive specimens. This paper also reports the results of controlled animal experiments which show the correlation between the types of antibodies produced during the course of immunization, and the titres obtained in serological tests utilizing pathogenic treponemes as antigen.

\section{Material and Methods}

\section{Antigens}

(1) Pathogenic Treponema pallidum Pathogenic treponemes of the Nichols strain were cultivated in rabbits by infecting the testes. Upon development of orchitis, usually 8-10 days after injection, the rabbits were killed, and the testes removed, cut, and shaken with 0.85 per cent. saline for 20 minutes. Treponemal suspensions thus obtained were purified from the various contaminants by differential centrifugation as described by Rathlev and Pfau (1965). Treponemes were re-

* Received for publication April 11, 1967. suspended in phosphate buffered saline, $\mathrm{pH} 6 \cdot 4$, to yield suspensions containing $1 \times 10^{8}$ organisms $/ \mathrm{ml}$. These were subsequently disrupted by ultra-sonication $(10 \mathrm{Kc}$, $15 \mathrm{~min}$.). One $\mathrm{ml}$. aliquots were frozen at $-20^{\circ} \mathrm{C}$. in separate tubes and could be thus preserved for several months without loss of activity. Heating or repeated freezing and thawing of the same aliquot of the lysate seemed to weaken its reactivity. A homogeneous suspension of the lysate is desirable. However, centrifugation of the lysate is not recommended, since it may result in sedimentation or exclusion of the antigens which are specific for the pathogenic treponemes and are located in the cell-wall portion of the organisms (Rathlev, 1967).

(2) Reiter treponemal lysate Reiter treponemes were grown in thioglycollate medium and washed five to six times by centrifugation to remove traces of the medium. After microscopic counting, the number of treponemes was adjusted to about $1 \times 10^{8} / \mathrm{ml}$. by addition of phosphate buffered saline, $\mathrm{pH} 6 \cdot 4$, and the organisms were ultra-sonicated as in the case of the pathogenic organisms. These were then frozen at $-20^{\circ} \mathrm{C}$. until required for use.

\section{Reiter Protein}

A weighed amount of lyophilized Reiter protein was suspended and homogenized in phosphate buffered saline, $\mathrm{pH} 6.4$, to a final concentration of 0.0015 per cent. $(w / v)$.

\section{Sera}

300 human 'sera, which were sent to the Statens Seruminstitut in Copenhagen for routine sero-diagnosis of syphilis, were investigated by the haemagglutination test (HA). Also sera from rabbits immunized with either live or killed Nichols treponemes were investigated at various intervals beginning on the sixth day after injection.

All sera were kept at $56^{\circ} \mathrm{C}$. for $30 \mathrm{~min}$. to inactivate complement, and were adsorbed with washed, packed sheep erythrocytes to remove non-specific haemagglutinins if present.

\section{Sheep Erythrocytes}

Formalinization of fresh, washed sheep erythrocytes was carried out according to the method of Weinbach (1959). Instead of formalinization, treatment with 
glutaraldehyde (Stavitsky, 1966) could also be used with success. It has the advantage of being a much quicker treatment and can be done on the day of the experiment. Formalinization or glutaraldehyde treatment was followed by treatment with tannic acid ( 0.005 per cent.) as described by Boyden (1951). It was shown by Fulthorpe (1959) that a linear log relationship exists between erythrocyte concentration and haemagglutination titre. Therefore it is important to standardize not only the concentration of the antigen, but also the density of the erythrocytes to ensure reproducible results. This was done by counting the treated cells in a haemocytometer.

\section{Conjugation of Erythrocytes with the Pathogenic Treponemal Antigen}

$10 \mathrm{ml}$. suspension of $2.5 \mathrm{ml}$. per cent. tanned erythrocytes was incubated with $1 \mathrm{ml}$. of the pathogenic treponemal lysate for $30 \mathrm{~min}$. at $37^{\circ} \mathrm{C}$. Cells were then washed and resuspended in $10 \mathrm{ml}$. phosphate buffered saline, $\mathrm{pH} 7 \cdot 2$.

\section{Diluent}

All sera were diluted in freshly prepared 1 per cent. normal rabbit serum (NRS). Addition of gelatin, polyvinylpyrrolidone (Borduas and Grabar, 1953) and Tween 80 (Tomizawa and Kasamatsu, 1966) were tried. However, in our procedure, these often produced nonspecific agglutination of normal control erythrocytes. Hence only inactivated, pre-adsorbed normal rabbit serum ( 1 per cent.) was used to dilute the sera.

\section{Controls}

A standard human syphilitic serum as a positive control and a standard normal serum as a negative control were always investigated in each experiment to test the reproducibility of the procedure.

\section{Haemagglutination-Inhibition Reaction}

Results of the haemagglutination test were further checked by a haemagglutination-inhibition reaction. This was done by pre-incubation of the antiserum, or preferably its serial dilutions, with the specific antigen before addition of sensitized cells. $0.1 \mathrm{ml}$. of 1:10 diluted, pathogenic treponemal lysate or Reiter treponeme lysate was added to each serial dilution. Inhibition experiments were also tried by pre-incubation with Reiter treponeme lysate or Reiter protein antigen.

\section{Procedure}

Plexiglass haemagglutination trays were used for serial dilutions of the antiserum. Two-fold serial dilutions of $0.3 \mathrm{ml}$. antiserum were made with 1 per cent. NRS, and finally $50 \mu \mathrm{l}$. suspension of sensitized erythrocytes was added to each diluted sample. Controls for the antigen and antiserum were made with each serum specimen. Titres or reciprocals of dilution ranged from 10 to 20,000. Results are expressed as follows:

$$
\begin{aligned}
& +=\text { positive reaction for titres up to } \\
& ++=\text { positive reaction for titres up to } 640 \\
& +++=\text { positive reaction for titres up to } 5,000 \\
& ++++=\text { positive reaction for titres up to } 20,000
\end{aligned}
$$$$
\text { or higher }
$$

\section{Results and Discussion}

The human sera investigated by haemagglutination (HA) were also tested by five other serodiagnostic methods for syphilis to evaluate the competence of the former as a routine test for syphilis sero-diagnosis. The tests chosen for comparison can be divided into two groups:

(1) The standard routine tests (STS) like complement-fixation with cardiolipin antigen (WR), Kahn standard reaction (KR), and Meinicke reaction (MR), which utilize non-treponemal lipoidal antigens (Schmidt, 1951).

(2) The Treponema pallidum immobilization test (TPI) as modified by Nielsen (1957) and the fluorescent treponemal antibody $\left(\mathrm{FTA}_{200}\right.$ ) test (Deacon, Freeman, and Harris, 1960), which use pathogenic treponemes as the antigen.

Table I presents results of the six tests on sera from some of the patients investigated. These were

\begin{tabular}{|c|c|c|c|c|c|c|c|c|c|c|c|}
\hline \multirow{2}{*}{$\begin{array}{l}\text { Patient } \\
\text { No. }\end{array}$} & \multicolumn{5}{|c|}{ History } & \multicolumn{3}{|c|}{$\begin{array}{l}\text { Tests with Pathogenic } \\
\text { Treponemal Antigens }\end{array}$} & \multicolumn{3}{|c|}{$\begin{array}{l}\text { Tests with } \\
\text { Lipoidal Antigens }\end{array}$} \\
\hline & $\begin{array}{l}\text { Type of } \\
\text { Syphilis }\end{array}$ & Sex & $\begin{array}{l}\text { Age } \\
\text { (yrs) }\end{array}$ & $\begin{array}{l}\text { Treatment } \\
\text { before Tests }\end{array}$ & Clinical Signs & HA & TPI & FTA (200) & WR & $\mathbf{K R}$ & MR \\
\hline $\begin{array}{r}1 \\
2 \\
3 \\
4 \\
5 \\
6 \\
7 \\
8 \\
9 \\
10 \\
11\end{array}$ & $\begin{array}{l}\text { None } \\
\text { None } \\
\text { None } \\
S_{1} \\
S_{1} \\
S_{1} \\
S_{2} \\
S_{2} \\
S_{2} \\
S_{2}-S_{3} \\
S_{2}-S_{3}\end{array}$ & $\begin{array}{l}\mathbf{F} \\
\mathbf{F} \\
\mathbf{M} \\
\mathbf{F} \\
\mathbf{F} \\
\mathbf{F} \\
\mathbf{F} \\
\mathbf{F} \\
\mathbf{F} \\
\mathbf{F}\end{array}$ & $\begin{array}{l}51 \\
19 \\
26 \\
28 \\
27 \\
40 \\
38 \\
32 \\
51 \\
22 \\
73\end{array}$ & $\begin{array}{l}\text { None } \\
\text { None } \\
\text { None } \\
\text { Penicillin } \\
\text { None } \\
\text { Penicillin } \\
\text { None } \\
\text { None } \\
\text { None } \\
\text { None } \\
\text { None }\end{array}$ & $\begin{array}{c}\text { None } \\
\text { Pregnancy } \\
\text { None } \\
\text { Chancre } \\
\text { Chancre } \\
\text { Chancre } \\
\text { Rash } \\
\text { Rash } \\
\text { Cerebrospinal syphilis } \\
\text { None } \\
\text { Dementia paralytica }\end{array}$ & $\begin{array}{r}- \\
-\vec{z} \\
++\overrightarrow{+} \\
++++ \\
+++ \\
+++ \\
+++ \\
++ \\
+++ \\
+++\end{array}$ & $\begin{array}{l}- \\
- \\
\overline{+} \\
+ \\
+ \\
+ \\
+ \\
+ \\
+ \\
+\end{array}$ & $\begin{array}{r}- \\
- \\
+++t \\
++++ \\
+++t \\
++++ \\
++++ \\
+++t \\
++++ \\
++++\end{array}$ & $\begin{array}{r}- \\
- \\
- \\
8 \\
14 \\
7 \\
10 \\
12 \\
7 \\
8 \\
16\end{array}$ & $\begin{array}{r}- \\
- \\
-3 \\
12 \\
3 \\
10 \\
10 \\
3 \\
3 \\
12\end{array}$ & $\begin{array}{r}\overline{-} \\
\bar{z} \\
+ \\
+\overline{+} \\
\overline{+} \\
+\overline{+} \\
++ \\
+ \\
+ \\
+ \\
+\end{array}$ \\
\hline
\end{tabular}
chosen from different stages of syphilis. A detailed

TABLE I

COMPARISON OF SERO-DIAGNOSTIC RESULTS ON SOME NORMAL AND SYPHILITIC SERA 
report on the rest of the sera will be published in a separate article. Table I shows good agreement between the results of haemagglutination and the other tests on the normal and syphilitic sera investigated. However, there is a striking difference in the results on biological false positive sera (Table II). These were specially selected from a FTA evaluation study, and were known to give conflicting results in various tests (Nielsen, Bentzon, and Larsen, 1967).

Since a crucial test for the specificity of a serological method is its performance with the biological false positive sera, it was of interest to study the results of $\mathrm{HA}$ with these sera and compare them with results of other tests.

As shown in Table II, haemagglutination results agree closely with the clinical findings, and perfectly with the results of TPI test, which is accepted as the most specific of all the current tests for syphilis (Nielsen and Reyn, 1956).

The high specificity of the haemagglutination results obtained is probably due more to the chemical nature and specificity of the antigen than to the method per se. Close agreement between the results of the TPI and HA tests indicates that perhaps the immobilisin-producing antigen is also the main antigen involved in the latter.

This hypothesis is supported by the haemagglutination-inhibition tests. Pre-incubation of the antisera with pathogenic treponeme lysate completely inhibited agglutination of sensitized erythrocytes. However, pre-incubation of the antisera with either Reiter treponeme lysate or Reiter protein at different concentrations only partially inhibited the agglutination, thus demonstrating a lack of absolute specificity of Reiter antigens against syphilitic sera. On the other hand, tanned erythrocytes sensitized with Reiter antigens were agglutinated by rabbit anti-Reiter sera. In this case, haemagglutination was completely inhibited by pre-incubation of rabbit anti-Reiter sera with Reiter antigens, but not with pathogenic treponeme lysate.

In the case of biological false positive sera, the disagreement between the results of TPI and HA on one hand, and of the STS and FTA (200) on the other, is noteworthy. The FTA test seems to detect not only the specific treponemal antibodies, but also the non-specific antibodies to lipoidal components which occur in non-treponemal infections. The nonspecificity of the original FTA test is reduced

TABLE II

COMPARISON OF SERO-DIAGNOSTIC RESULTS ON BIOLOGICAL FALSE POSITIVE SERA

\begin{tabular}{|c|c|c|c|c|c|c|c|c|c|}
\hline \multirow{2}{*}{ Patient No. } & \multirow{2}{*}{ Sex } & \multirow{2}{*}{ Age (yrs) } & \multirow{2}{*}{$\frac{\text { History }}{\text { Clinical Diagnosis }}$} & \multicolumn{3}{|c|}{$\begin{array}{l}\text { Tests with Pathogenic } \\
\text { Treponemal Antigens }\end{array}$} & \multicolumn{3}{|c|}{$\begin{array}{c}\text { Tests with } \\
\text { Lipoidal Antigens }\end{array}$} \\
\hline & & & & HA & TPI & FTA(200) & WR & KR & $\mathbf{M R}$ \\
\hline 101 & $\mathbf{M}$ & 88 & Cancer ventriculi & - & - & ++ & 8 & 1 & + \\
\hline 102 & $\mathbf{F}$ & 78 & $\begin{array}{l}\text { Splenomegaly } \\
\text { Disseminated lupus } \\
\text { erythematosus }\end{array}$ & - & - & - & 12 & 12 & n.d. \\
\hline 103 & $\mathbf{M}$ & 35 & None & - & - & - & 5 & 5 & + \\
\hline 104 & $\mathbf{F}$ & 79 & $\begin{array}{l}\text { Arterial sclerosis } \\
\text { Achylia gastrica }\end{array}$ & - & - & - & 9 & 10 & ++ \\
\hline 105 & $\mathbf{F}$ & 77 & Apoplexia cerebri & - & - & ++ & - & 8 & ++ \\
\hline 106 & $\mathbf{F}$ & 85 & Chronic polyarthritis & - & - & + & 4 & 2 & ++ \\
\hline 107 & $\mathbf{F}$ & 76 & Ulcus varicosum cruris & - & - & ++ & 10 & 7 & ++ \\
\hline 108 & $\mathbf{F}$ & 70 & Diabetes mellitus & - & - & - & 5 & 7 & ++ \\
\hline 109 & $\mathrm{~F}$ & 24 & Hyperthyroidism & - & - & ++ & 5 & 4 & + \\
\hline 110 & $\mathbf{F}$ & 32 & Pregnancy, no pathological signs & - & - & + & 5 & 5 & ++ \\
\hline 111 & $\mathbf{M}$ & 65 & $\begin{array}{c}\text { Splenomegaly } \\
\text { Hepatomegaly }\end{array}$ & - & - & - & 20 & 14 & \pm \\
\hline 112 & $\mathbf{F}$ & 34 & $\begin{array}{l}\text { Collagenosis } \\
\text { Aortic stenosis }\end{array}$ & - & - & + & 6 & 6 & ++ \\
\hline 113 & $\mathbf{F}$ & 73 & $\begin{array}{l}\text { Leukaemia } \\
\text { Waldenström's syndrome }\end{array}$ & - & - & - & 17 & 12 & ++ \\
\hline 114 & $\mathbf{F}$ & 84 & $\begin{array}{l}\text { Neoplasm of the oesophagus } \\
\text { with metastasis }\end{array}$ & - & - & ++ & 2 & 2 & \pm \\
\hline
\end{tabular}


considerably in the FTA (200) modification. However, as shown in Table II, the latter still shows an occasional non-specific reactivity.

The non-specific antibodies which are produced in "auto-immune" diseases in consequence of pathologically altered tissues, do not seem to be effective in the HA test. The explanation can be perhaps found in the selective affinity of tanned erythrocytes for proteins or protein-polysaccharide complexes rather than for lipid antigens. It is not unlikely that tanned erythrocytes conjugate preferentially with the "protein-rich" antigens, thereby excluding, so to say, the lipid components of the treponemes from taking part in the reaction.

The sensitivity or the ability to detect syphilitic antibodies as a positive reaction was also satisfactory with the HA test. Sera from immunized rabbits were analysed for the type of antibodies present, and the competence of HA, TPI, and FTA (200) tests in detecting early antibodies was investigated (Table III).

Ten rabbits (Group A) were infected with pathogenic treponemes and six other rabbits (Group B) were immunized with the same number of killed treponemes. From the sixth day after injection, sera from the immunized animals were collected and investigated in the three tests. An aliquot of each sample was centrifuged in a sucrose density gradient (Kunkel, 1960) to determine the molecular type of the antibody present. The Figure shows the results on 8th-day serum (Group A) and 20th-day serum (Group B) samples. The early antibody from Day 8 in Group A and Day 12 in Group B is predominantly of $\gamma \mathrm{M}$ type. Of the three tests, shown in Table III, only FTA (200) and HA gave positive results from Day 8 to Day 20.

The haemagglutination reaction has been shown to be very sensitive in detecting $\gamma \mathrm{M}$ antibody (Stavitsky, 1964), which endows it with the high sensitivity comparable to that of the FTA test in detecting antibodies produced very early in

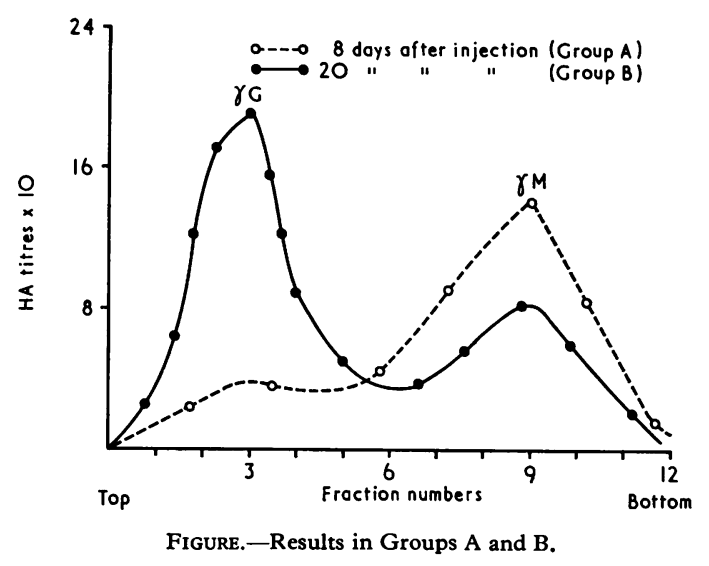

syphilitic infections. This observation is based mainly on investigations on immunized rabbits, since experimental conditions could be wellcontrolled. Sera from patients in the very early stages of syphilis are being investigated by the HA, TPI, and FTA (200) tests, and a comparison of their sensitivity to detect early syphilitic antibodies in humans will be presented soon.

The TPI test, on the other hand, is more sensitive in detecting the $\gamma \mathrm{G}$ antibody of the hyperimmune stage (Holst, 1965) and therefore does not give positive results till sufficient $\gamma \mathrm{G}$ antibody of the secondary response is present.

The HA test thus showed both high specificity and sensitivity to recommend itself as a routine test in syphilis serology. It should be emphasized, however, that, as in any other reliable procedure, careful handling and standardization of all materials are important for reproducible results.

From a practical point of view, simplicity of equipment makes the HA test quite suitable for routine sero-diagnosis and it can be performed in ordinary modest laboratories that do not have access to dark-field or fluorescent microscopes. Compared

TABLE III

COMPARISON OF RESULTS OF HA, TPI, AND FTA ON RABBIT IMMUNE SERA

\begin{tabular}{|c|c|c|c|c|c|c|}
\hline \multirow{2}{*}{ Day after Injection } & \multicolumn{2}{|c|}{ HA } & \multicolumn{2}{|c|}{ FTA (200) } & \multicolumn{2}{|c|}{ TPI } \\
\hline & Group A & Group B & Group A & Group B & Group A & Group B \\
\hline 0 (before injection) & - & - & - & - & - & - \\
\hline $\begin{array}{r}6 \\
8 \\
10 \\
12 \\
16 \\
20\end{array}$ & $\begin{array}{r}\bar{r} \\
+ \\
+ \\
++ \\
\text { n.d. } \\
\text { n.d. }\end{array}$ & $\begin{array}{r}- \\
\overline{-} \\
+ \\
+ \\
+\end{array}$ & $\begin{array}{r}\bar{y} \\
+ \\
++ \\
++ \\
\text { n.d } \\
\text { n.d. }\end{array}$ & $\begin{array}{r}- \\
+ \\
+ \\
+ \\
+ \\
++\end{array}$ & $\begin{array}{r}\overline{-} \\
\bar{z} \\
\overline{\bar{n}} \text { n.d. } \\
\text { n.d. }\end{array}$ & $\begin{array}{l}\overline{-} \\
\overline{-} \\
\overline{+}\end{array}$ \\
\hline
\end{tabular}


to the TPI test, haemagglutination is more economical since less antigenic material is needed; $1 \mathrm{ml}$. of the lysate (approx. $1 \times 10^{8}$ treponemes) is adequate for testing fifty serum samples quantitatively with ten titres for each, while the same number of treponemes is used for $\mathbf{2 5}$ sera only in a qualitative TPI test.

\section{Summary}

Formalinized tanned sheep erythrocytes were conjugated with antigens from a lysate of the Nichols treponemes. About 300 human sera, including biological false positive, normal, and syphilitic specimens, were investigated in a haemagglutination test.

The results indicate that the haemagglutination test has a specificity similar to that of the TPI test and a sensitivity comparable to that of the FTA (fluorescent treponemal antibody) test. Its reliability and simplicity perhaps indicate a promising future for the test in the sero-diagnosis of syphilis.

This study was made possible by a grant from the World Health Organization. The author acknowledges the excellent technical assistance of Anne Knudsen and valuable suggestions and encouragement from $\mathrm{Dr} \mathrm{H}$. A. Nielsen.

Lyophilized Reiter protein was generously supplied by Dr J. H. De Bruijn of the National Institute of Public Health, Utrecht, The Netherlands.

\section{REFERENCES}

Bachmann, W. (1932). Klin. Wschr., 11, 1878.

Blumenthal, G. (1932). Ibid., 11, 1466.

Borduas, A. G., and Grabar, P. (1953). Ann. Inst. Pasteur, 84, 903.

Boyden, S. (1951). F. exp. Med., 93, 107.

D'Alessandro, G. (1958). "Reiter Treponema Antigen", in "IX Annual Symposium on Recent Advances in the Study of Venereal Diseases, Philadelphia: Digest of Proceedings", paper 12. U.S.P.H.S., Atlanta, Georgia.
Deacon, W. E., Freeman, E. M., and Harris, A. (1960). Proc. Soc. exp. Biol. (N.Y.). 103, 827.

Fulthorpe, A. J. (1959). Immunology, 2, 104.

Holst, E. (1965). Unpublished results.

Kunkel, H. G. (1960). In "The Plasma Proteins", ed. F. W. Putman, vol. 1, p. 279. Academic Press, New York.

Lamedica, G., and Robert, L. (1957). Ig. mod., 50, 345.

Nielsen, H. A. (1957). Acta path. microbiol. scand., 40, 119.

—, Bentzon, M. W., and Larsen, S. O. (1967). Unpublished results. and Reyn, A. (1956). Bull. Wld Hlth Org., 14, 263.

Rathlev, T. (1965). VDT/RES/77.65. WHO, Geneva. (1967). Unpublished results. and Pfau, C. J. (1965). Scand. F. clin. Lab. Invest., $17,130$.

Roemer, G. B., and Schlipköter, H. W. (1953). Dtsch. med. Wschr., 78, 345.

Schmidt, H. (1951). Brit. F. vener. Dis., 27, 23.

Stavitsky, A. B. (1964). In "Immunological Methods", a Symposium organized by the C.I.O.M.S., ed. J. F. Ackroyd, p. 363. Blackwell, Oxford. (1966). Personal communication.

Tomizawa, T., and Kasamatsu, S. (1966). fap. F. med. Sci. Biol., 19, 305.

Weinbach, R. (1959). Schweiz. Z. allg. Path., 22, 1.

Test d'hémagglutination utilisant l'antigène du Treponema pallidum pathogène pour le sérodiagnostic de la syphilis

RÉSUMÉ

Des érythrocytes de mouton formolées et tannées ont été conjuguées avec l'antigène venant du lysat de tréponème de Nichols. Environ trois cents sérums humains, comprenant des échantillons ayant donné une réaction biologique faussement positive, des échantillons normaux et des sérums syphilitiques, ont été soumis à l'épreuve d'hémagglutination.

Les résultats indiquent que le test d'hémagglutination a la spécificité du TIT et également une sensibilité comparable à celle du test d'immunofluorescence utilisant l'anticorps antitréponème (FTA). Les caractères de réproducibilité et de simplicité peut-être permettent-ils d'augurer un avenir prometteur pour le test appliqué au sérodiagnostic de la syphilis. 